
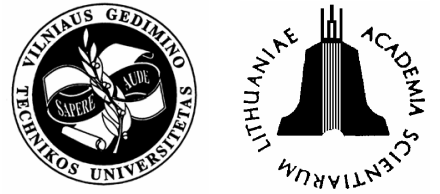

ISSN 1648-4142 print / ISSN 1648-3480 online TRANSPORT

www.transport.vgtu.lt

Transport - 2006, Vol XXI, No 4, II a-II c

\title{
Publicity
}

\section{THE ANNIVERSARY: THE JOURNAL “TRANSPORT” - 20 YEARS TOGETHER!}

\author{
Olegas Prentkovskis \\ Managing Editor of Journal “TRANSPORT”, Vilnius Gediminas Technical University, \\ Plytinès g. 27, LT-10105 Vilnius, Lithuania. \\ Phone: +370 5274 4784. E-mail: olegas@ti.vtu.lt \\ Received 3 July 2006, accepted 4 September 2006
}

\begin{abstract}
The history of Journal "TRANSPORT" - covers, titles, ISSN, languages of publications - from 1986 to 2006 is presented. Journal's fields of research are mentioned. International databases of scientific information, which include abstracted or full text papers of Journal, are mentioned. Journal Editorial Board staff by countries is presented. Countries, from which the researchers published papers in Journal, are mentioned.
\end{abstract}

Keywords: Journal "TRANSPORT”, anniversary, history, fields of research.

Transport is one of the key branches of economy. The development of economy can hardly be imagined without transport now. The reliable and well organized transport services are required for efficient performance of industry, construction and agriculture. Public mood and the efficiency of people's work also largely depend on transport system and its performance.

Therefore, satisfying the demand of people for quality transport services provided in due time is becoming a social, rather than a merely transport problem, determining the attitude of the population not only to the level of the provided transport services, but to all processes taking place in a particular country.

Continually growing transportation by motor vehicles is accompanied by increasing demands for higher quality of transport services and higher efficiency of transport performance.

Harmonized development of state economy requires that more attention be paid to the problems of organization and management of automobile transport by all engaged in providing transport services. This in turn requires more effective planning as well as analysis and evaluation of various economic aspects of the performance of large transport systems and individual motor vehicles. Precise calculation and analysis are key factors in developing rational schemes of energy-efficient freight transportation. An effective economic solution makes a basis for successful development of transport enterprises, ensuring their profitable work.

Transportation is performed by transport facilities which are becoming more and more compli- cated, as far as their design, structures and operational principles are concerned.

One of the main tasks of transport is the increase of the amount of the transported goods as well as retaining traffic safety.

The harmonized operation of transport facilities largely depends on many factors. Most of them have a negative effect on transport performance, e. g. poor roads, inefficient organization of road traffic, poor technical state of transport facilities, bad weather or visibility, high density of traffic flows, the choice of inappropriate motor vehicle speed etc.

At present, joint efforts of transport specialists and the governing institutions of country are required to develop and enhance the performance of a national transport system. Theoretical and empirical research in the area of transport is also need.

It is well-known that publishing of technical literature can do much for disseminating the innovative ideas and developments in particular research areas. The same applies to area of transport.

A reviewed scientific Journal "TRANSPORT" is published by Vilnius Gediminas Technical University and Lithuanian Academy of Sciences.

The papers published in the Journal deal with the following problems:

- transport policy,

- fundamentals of the transport system,

- transportation technology of passengers and freight: by road, by railway, by inland waterways, by sea and by air,

- multimodal transportation technology and logistics, 
The history of the Journal is presented in the Table:

\begin{tabular}{|c|c|c|c|}
\hline $\begin{array}{c}\text { Cover of the } \\
\text { Journal }\end{array}$ & The title of the Journal & $\begin{array}{c}\text { ISSN, years of pub- } \\
\text { lishing, volumes }\end{array}$ & Languages of publications \\
\hline $\mid \equiv$ & $\begin{array}{l}\text { Proceedings of the higher } \\
\text { schools of Lithuania } \\
\text { “Automobiliu transportas" } \\
\text { “Автомобильный транспорт” }\end{array}$ & $\begin{array}{c}\text { ISSN 0136-1589 } \\
\text { 1986-1991 } \\
\text { Vol 1-6 } \\
\text { One Vol = One No }\end{array}$ & $\begin{array}{l}\text { All Volumes: } \\
\text { - Publications in Russian } \\
\text { - Summaries in Lithuanian and } \\
\text { English }\end{array}$ \\
\hline & $\begin{array}{c}\text { Proceedings of Vilnius Technical } \\
\text { University } \\
\text { "Transportas" } \\
\text { “Transport Engineering" }\end{array}$ & $\begin{array}{c}\text { ISSN 0136-1589 } \\
\begin{array}{c}\text { 1992-1994 } \\
\text { Vol 7-9 } \\
\text { One Vol = One No }\end{array}\end{array}$ & $\begin{array}{l}\text { Vol 7: } \\
\text { - Publications in Russian } \\
\text { - Summaries in Lithuanian and } \\
\text { English } \\
\text { Vol 8: } \\
\text { - Publications in English without } \\
\text { Summaries } \\
\text { Vol 9: } \\
\text { - Publications in Lithuanian and } \\
\text { - English } \\
\text { - Summaries in English } \\
\end{array}$ \\
\hline Transportas & $\begin{array}{c}\text { Research Journal of Vilnius } \\
\text { Gediminas Technical University } \\
\text { and Lithuanian Academy } \\
\text { of Sciences } \\
\text { "Transportas" } \\
\text { "Transport Engineering" } \\
\text { "Tpaнспорт" }\end{array}$ & 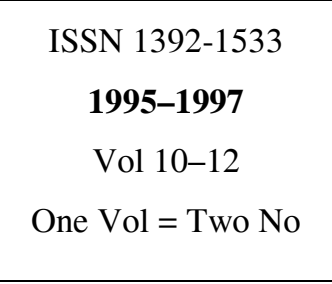 & \multirow{3}{*}{$\begin{array}{l}\text { All Volumes: } \\
\text { - Publications in Lithuanian, } \\
\text { English and Russian } \\
\text { - Summaries in Lithuanian, Eng- } \\
\text { lish and Russian }\end{array}$} \\
\hline$T_{R A}$ & \multirow{2}{*}{$\begin{array}{c}\text { Research Journal of Vilnius } \\
\text { Gediminas Technical University } \\
\text { and Lithuanian Academy } \\
\text { of Sciences } \\
\text { "Transportas" } \\
\text { "Transport Engineering" }\end{array}$} & $\begin{array}{c}\text { ISSN 1392-1533 } \\
\text { 1998-2000 } \\
\text { Vol 13-15 } \\
\text { One Vol = Six No } \\
\end{array}$ & \\
\hline$E$ & & $\begin{array}{c}\text { ISSN 1392-1533 } \\
\mathbf{2 0 0 1} \\
\text { Vol } 16 \\
\text { One Vol = Six No }\end{array}$ & \\
\hline Q i & \multirow[b]{2}{*}{$\begin{array}{l}\text { Research Journal of Vilnius Ge- } \\
\text { diminas Technical University and } \\
\text { Lithuanian Academy of Sciences } \\
\text { "Transport" }\end{array}$} & $\begin{array}{c}\text { ISSN 1648-4142 } \\
\mathbf{2 0 0 2 - 2 0 0 5} \\
\text { Vol 17-20 } \\
\text { One Vol = Six No }\end{array}$ & \multirow[b]{2}{*}{$\begin{array}{l}\text { All Volumes: } \\
\text { - Publications in English } \\
\text { - Summaries in English, Lithua- } \\
\text { nian and Russian }\end{array}$} \\
\hline 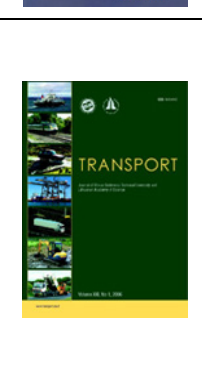 & & $\begin{array}{c}\text { ISSN 1648-4142 print } \\
\text { ISSN 1648-3480 } \\
\text { online } \\
\text { since } 2006 \\
\text { Vol } 21 \text { and other } \\
\text { One Vol = Four No }\end{array}$ & \\
\hline
\end{tabular}


- loading technology,

- roads, railways, airports, ports,

- pipeline transport,

- production and technological transport,

- agricultural motor vehicles,

- traffic safety and environment protection,

- motor vehicles: design, manufacture and exploitation,

- transport power engineering,

- fuels, lubricants and maintenance materials,

- common work of customs and transport,

- insurance,

- information technology in transport,

- transport economics and management,

- transport law,

- transport standards,

- transport education, transport history.

The information about the papers published in Journal "TRANSPORT" is available in the form of summaries and complete texts in the respective international databases of scientific information:

- COMPENDEX (Elsevier Database),

- EBSCO Current Abstracts (EBSCO Publishing),

- PAPERCHEM (Elsevier Database),

- SCOPUS (Elsevier Database),

- ICONDA (The International Construction Database),

- VINITI (Database of All-Russian Scientific and Technical Information Institute of Russian Academy of Sciences for Scientific and Technical Information),

- CAMBRIDGE SCIENTIFIC ABSTRACTS.

Since 1986 the Editor-in-Chief of the Journal has been Prof. Dr. Habil. Adolfas Baublys.

Since the beginning of the Journal publication, the status of the Editorial Board has changed from national to international. Now the staff of the Editorial Board included 19 members. 7 members carrying out research in transport engineering represent 3 largest Lithuanian universities (Vilnius Gediminas Technical University, Kaunas University of Technology and Klaipeda University). While 12 members of the Editorial Board are from research institutes (or universities) located in Belarus, Croatia, Estonia, Finland, Germany, Latvia, Poland, Russia, the United Kingdom and the USA. A list of the members of the Editorial Board can be found on the second page of the Journal.

The researchers from Lithuania and other countries, including Belarus, Bulgaria, Estonia, India, Iran, Latvia, Nigeria, Poland, Russia, Slovakia, Serbia and Montenegro, Ukraine etc, publish the results of their investigations in Journal "TRANSPORT".
The official website of the Journal www.transport.vgtu.lt, is accessible in Lithuanian, English and Russian. There you can find:

- the staff and address of the Editorial Board of the Journal,

- the requirements to publications and their formatting,

- complete texts of the published papers and their summaries.

Contributors from all countries are welcome to report on their research in the reviewed Journal "TRANSPORT" published by Vilnius Gediminas Technical University and theLithuanian Academy of Sciences! 